\title{
Genetic risk score predicting accelerated progression from mild cognitive impairment to Alzheimer's disease
}

E. Rodríguez-Rodríguez ${ }^{1}$, P. Sánchez-Juan ${ }^{1}$, J.L. Vázquez-Higuera ${ }^{1}$, I. Mateo ${ }^{1}$, A. Pozueta

${ }^{1}$, J. Berciano ${ }^{1}$, S. Cervantes ${ }^{2}$, D. Alcolea ${ }^{3}$, P. Martínez-Lage ${ }^{4}$, J. Clarimón $^{3}$, A. Lleó ${ }^{3}$, P. Pastor $^{2,5}$, O. Combarros ${ }^{1, *}$

${ }^{1}$ Neurology Department and CIBERNED, “Marqués de Valdecilla” University Hospital (University of Cantabria and IFIMAV), Santander, Spain.

${ }^{2}$ Division of Neurosciences, Center for Applied Medical Research, University of Navarra, Pamplona, Spain.

${ }^{3}$ Neurology Department and CIBERNED, Hospital de la Santa Creu i Sant Pau, Universitat Autònoma de Barcelona, Barcelona, Spain.

${ }^{4}$ Fundación CITA-Alzheimer, San Sebastián, Spain.

${ }^{5}$ Neurology Department and CIBERNED, Clínica Universidad de Navarra, Pamplona, Spain.

${ }^{*}$ Correspondence: Dr. O. Combarros, Neurology Service, University Hospital “Marqués de Valdecilla”, 39008-Santander, Spain. Tel.: +34 942202507; fax: +34 942202655; E-mail address: combarro@unican.es 


\section{Summary}

Aside from APOE, the genetic factors that influence in the progression from mild cognitive impairment (MCI) to Alzheimer's disease (AD) remain largely unknown. We assessed whether a genetic risk score (GRS), based on 8 non-APOE genetic variants previously associated with AD risk in genome-wide association studies, is associated with either risk of conversion or with rapid progression from MCI to AD. Among 288 subjects with MCI, follow-up (mean 26.3 months) identified 118 MCI-converters to AD and 170 MCInonconverters. We genotyped ABCA7 rs3764650, BIN1 rs744373, CD2AP rs9296559, CLU rs1113600, CR1 rs1408077, MS4A4E rs670139, MS4A6A rs610932, and PICALM rs3851179. For each subject we calculated a cumulative GRS, defined as the number of risk alleles (range 0-16) with each allele weighted by the AD risk odds ratio. GRS was not associated with risk of conversion from MCI to AD. However, MCI-converters to AD harboring 6 or more risk alleles (second and third GRS tertiles) progressed 2-fold more rapidly to $\mathrm{AD}$ when compared with those with less than 6 risk alleles (first GRS tertile). Our GRS is a first step toward development of prediction models for conversion from MCI to AD that incorporate aggregate genetic factors.

Keywords: Mild Cognitive Impairment, Alzheimer's disease, Conversion, Genetics, Risk, Genetic Risk Score 


\section{Introduction}

There has been a lot of interest in the detection of predictors of conversion from mild cognitive impairment (MCI) to Alzheimer's disease (AD) using neuroimaging methods, CSF biomarkers and cognitive tests (Jack et al., 2010; Landau et al., 2010; Davatzikos et al., 2011). Despite the many genetic studies of AD, there has been little research directed toward determining the influence of genetic variation on progression from MCI to AD (Reitz and Mayeux 2010). While the $\varepsilon 4$ allele of APOE is the major genetic risk factor for $\mathrm{AD}$, recent genome-wide association studies (GWASs) have identified several susceptibility loci for AD (Harold et al., 2009; Lambert et al., 2009; Seshadri et al., 2010; Hollingworth et al., 2011; Naj et al., 2011), but most of these risk alleles have shown only a modest effect (odds ratios between 0.88 and 1.23). Previous studies have shown that combining multiple loci with modest effects into a global genetic risk score (GRS) might improve identification of persons who are at risk for common complex diseases, such as coronary heart disease (Ripatti et al., 2010), type 2 diabetes (Cornelis et al., 2009), rheumatoid arthritis (Karlson et al., 2010), or multiple sclerosis (De Jager et al., 2009). To our knowledge, no study has examined the joint effects of previously reported AD-predisposing loci derived from GWASs on the risk of conversion from MCI to AD.

We investigated the relationship between 8 non-APOE AD risk alleles (ABCA7 rs3764650, BIN1 rs744373, CD2AP rs9296559, CLU rs1113600, CR1 rs1408077, MS4A4E rs670139, MS4A6A rs610932, and PICALM rs3851179), considered individually and as cumulative GRS, with two goals: first to characterize the conversion risk from MCI to AD, and then to investigate the velocity of progression in MCI-converters to AD.

\section{Material and methods}

Subjects 
We examined 297 consecutive patients who attended the Departments of Neurology of University Hospital “Marqués de Valdecilla” (Santander, Spain), Hospital de la Santa Creu i Sant Pau (Barcelona, Spain), and Clínica Universidad de Navarra (Pamplona, Spain) and that fulfilled the Petersen criteria for amnestic MCI (Petersen et al., 2001). The time of onset of MCI was ascertained from informants' estimates. All patients underwent a complete clinical and neuropsychological evaluation at baseline and at 6-month intervals. General cognitive function was assessed using MMSE, data on activities of daily living were collected using the Interview for Deterioration in Daily living activities in Dementia (IDDD), and symptoms of depression were measured using the Hamilton Rating Scale for Depression.

Neuropsychological battery included test for the assessment of memory (California Verbal Learning Test-CVLT), language and semantic memory (15-items short-form of the Boston Naming Test, category fluency), praxis and visuospatial skills (Rey complex figure copy and WAIS block design subtest), attention and executive function (Symbol Digit Modalities Test, Trail Making part A and B, Stroop interference Test, Frontal Assessment Battery, category and letter fluency). A cognitive domain was judged as impaired when subjects scored 1.5 SD below values for age and education matched controls in at least one test. The development of dementia was established by consensus between the group members (at least 2 neurologists and 1 neuropsychologist) when a functional and/or neuropsychological decline was observed, and patient fulfilled DSM-IV criteria for dementia and NINCDS-ADRDA criteria for AD. During the follow-up period, 118 MCI patients were diagnosed as MCI-converters to AD (51\% women; mean age 75.2 years, SD 5.6, range 60-89 years; mean follow-up 26.3 months, SD 13.2, range 5-82 months); nine additional MCI patients converted to non-AD dementias (dementia with Lewy bodies in five, frontotemporal dementia in two, and vascular dementia in two others). $170 \mathrm{MCI}$ were classified as MCI-nonconverters to AD (47\% women; mean 
age 73.2 years, SD 6.5, range 57-86 years; mean follow-up 26.3 months, SD 12.7, range 1272 months).

Genotyping.

Blood samples were taken after written informed consent had been obtained from the subjects or their representatives. The study was approved by the ethical committees of the University Hospital “Marqués de Valdecilla”, Hospital de la Santa Creu i Sant Pau, and Clínica Universidad de Navarra. Genotyping of ABCA7 rs3764650, BIN1 rs744373, CD2AP rs9296559, CLU rs1113600, CR1 rs1408077, MS4A4E rs670139, MS4A6A rs610932, and PICALM rs3851179 was performed using a Taq-Man single-nucleotide-polymorphism assay (Applied Biosystems, Warrington, Cheshire, UK) and an ABI PRISM 7000 or $7900 \mathrm{HT}$ sequence detection systems (Applied Biosystems). References for each of the selected genes and single nucleotide polymorphisms are provided with the AlzGene database (Bertram et al., 2007). We used a dominant model comparing the homozygote for the non-risk allele to the combined heterozygote and homozygote for the risk allele.

Statistical analysis.

In addition to assessing each individual SNP (Model 1), we developed a weighted GRS (Model 2) where the weight is the allelic odds ratio for each allele as described in AlzGene database (Bertram et al., 2007). The weighted GRS was calculated by multiplying the number of risk alleles for each SNP $(0,1$, or 2$)$ by the weight for that SNP, and then taking the sum across the 8 SNPs. We divided the continuous GRS into tertiles and compared risk between them. Logistic regression was used to assess whether the conversion risk from MCI to AD was associated with the individual SNPs or the GRS divided into tertiles. Cox regression was used to assess the association with time-to-conversion. To exclude the possibility that differences in both the conversion risk and time-to-conversion were due to the dominant role of APOE $\varepsilon 4$ allele, GRS was calculated without the largest effect size of APOE $\varepsilon 4$ allele. 
Since each of the 8 reported SNPs has previously been associated with AD at significance levels exceeding a stringent GWAS threshold AD $\left(P<5 \times 10^{-8}\right)$ (Harold et al., 2009; Lambert et al., 2009; Seshadri et al., 2010; Hollingworth et al., 2011; Naj et al., 2011), we did not perform a Bonferroni adjustment and in this report we regarded an association to be significant if a two-sided p-value was less than 0.05 (for the same risk allele in the same direction as in the original report).

\section{Results}

As shown in Model 1, we first examined each individual genetic variant for both conversion risk from MCI to AD (Table 1) and velocity of conversion in MCI-converters to AD (Table 2), with APOE $\varepsilon 4$ allele being significantly associated with conversion risk (OR $=4.63,95 \%$ $\mathrm{CI}=2.15-9.98, p<0.001)$ and rapid progression $(\mathrm{HR}=1.77,95 \% \mathrm{CI}=1.05-2.97, p=0.03) . \mathrm{In}$ addition, CLU (rs1113600) was associated with a decreased conversion risk (Table 1, OR = 0.25, 95\% CI $=0.07-0.84, p=0.025$ ), whereas CD2AP (rs9296559) conferred a marginally significant association with a more rapid progression to $\mathrm{AD}$ (Table $2, \mathrm{HR}=1.69,95 \% \mathrm{CI}=$ 0.99-2.85, $p=0.051)$.

In model 2, we next evaluated the joint effects of the 8 non-APOE SNPs as a cumulative GRS, and GRS (adjusted for age, sex and APOE) was not associated with risk of conversion from MCI to AD (Table 1). However, MCI-converters to AD harboring 6 or more risk alleles progressed 2-fold more rapidly to AD compared with those having less than 6 risk alleles (Table 2): both MCI-converters in the second GRS tertile (mean GRS = 6.9, Hazard Ratio $=1.89,95 \% \mathrm{CI}=1.01-3.56, p=0.047$ ) and in the third GRS tertile (mean GRS $=9.9$, $\mathrm{HR}=2.06,95 \% \mathrm{CI}=1.07-3.98, p=0.031)$ showed a faster progression when compared with those in the first GRS tertile (mean GRS = 4.6). Cox survival analysis graph (Fig. 1) showed that MCI-converters in the second and third GRS tertiles progressed more rapidly to AD 
(mean time to conversion 26.4 months, SD 10.8) than MCI-converters in the first GRS tertile (mean time to conversion 31.2 months, SD 18.9). We did not explore the correlation between GRS and severity of AD development.

\section{Discussion}

MCI patients with the APOE $\varepsilon 4$ allele have been described to be more likely to convert to AD as compared to those without the APOE $\varepsilon 4$ allele (Elias-Sonnenschein et al., 2011), but these studies of MCI conversion to AD frequently do not account for time-dependent progression (Reitz and Mayeux, 2010). In our series, APOE $\varepsilon 4$ allele was significantly associated with both an increased conversion rate from MCI to AD and a shortened time-to-progression; consistent with these results, we recently also observed that APOE $\varepsilon 4$ allele reduced time-toprogression in MCI-converters (Samaranch et al., 2010). The extent to which genetic variability other than APOE influences the conversion from MCI to AD is unknown (Cervantes et al., 2011). Microtubule-associated protein tau (MAPT H1/H2) H1/H1 haplotype (Samaranch et al., 2010), vascular endothelial growth factor (VEGF rs699947) AA genotype (Chiappelli et al., 2006), brain-derived neurotrophic factor (BDNF rs6265) Met allele (Forlenza et al., 2010), and butyrylcholinesterase (BuChE rs1803274) Wt allele (Ferris et al., 2009) were associated with a higher risk of AD-conversion in MCI patients. In addition, MAPT H1/H1 (Samaranch et al., 2010), alpha 1-antichymotripsin (SERPINA3 rs4934) AA+AT genotypes (Barabash et al., 2009), and caspase-1 (CASP1 rs580253) CT+TT genotypes (Pozueta et al., 2011) were associated with a shortened time-to-progression in MCI-converters to AD.

It is not clear how to utilize genetic information for prediction of conversion risk from MCI to AD in clinical practice. A critical first step is to understand the role of aggregate genetic risk factors (GRS) rather than the association of individual alleles with this risk. 
Toward this end, we selected 8 SNPs that had a strong association with AD in recently published GWASs (Harold et al., 2009; Lambert et al., 2009; Seshadri et al., 2010; Hollingworth et al., 2011; Naj et al., 2011), to derive an aggregate GRS in MCI patients. We found that GRS did not show a good discrimination between MCI-converters and MCInonconverters to AD (Table 1). However, while the 8 non-APOE SNPs had little or no predictive power individually, their combined addition in a composite GRS predicted an accelerated progression to AD in MCI-converters (Table 2): MCI-converters in the second and third GRS tertiles had a 2-fold more rapid progression to AD than those in the first GRS tertile, accelerating the progression by an average of 5 months. Notably, the predictive capability of accelerated progression for the APOE $\varepsilon 4$ allele alone $(\mathrm{HR}=1.77)$ was nearly as good as that of the other 8 non-APOE loci combined in the GRS. The period of clinical follow-up of MCI was relatively short with a mean follow-up time of 26.3 months. An ever more extensive follow-up time of MCI-nonconverters to AD patients in our study might increase the specificity of our GRS as predictor of conversion from MCI to AD, because some of the MCI-nonconverters to AD might still develop AD later on. However, examining the time-dependent evolution of MCI to dementia over an observation period of 6 years, Busse et al. (2006) found that conversion rates to dementia in people with MCI were highest during the first interval of observation, which was 18 months in that study. We did not evaluate any biomarker to predict conversion and reinforce our genetic analysis.

For each patient, the identification of a single polymorphism that is common in the general population but has a small risk effect is not informative. Our study demonstrates the feasibility and potential utility of simultaneously considering the joint effects of 8 common genetic variants aggregated as a GRS, to predict a more rapid progression in MCI-converters to AD. These data need to be confirmed in further studies, and as new susceptibility variants are identified, GRS will need to be periodically updated. 


\section{Acknowledgement}

C. Sánchez-Quintana was involved in the DNA sample collections from Santander. This study was supported by grants from CIBERNED (CB06/07/0037) and from the Department of Health of the Government of Navarra (refs. 13085 and 3/2008). 


\section{References}

Barabash A, Marcos A, Ancín I, Vázquez-Alvarez B, de Ugarte C, Gil P, Fernández C, Encinas M, López-Ibor JJ, Cabranes JA (2009) APOE, ACT and CHRNA7 genes in the conversion from amnestic mild cognitive impairment to Alzheimer's disease. Neurobiol Aging 30: 1254-1264.

Bertram L, McQueen MB, Mullin K, Blacker D, Tanzi RE (2007) Systematic meta-analyses of Alzheimer disease genetic association studies: the AlzGene database. Nat Genet 39: $17-23$.

Busse A, Matthias C, Angermeyer C, Riedel-Heller SG (2006) Progression of mild cognitive impairment to dementia: a challenge to current thinking. Brit J Psychiatry 189: 399-404.

Cervantes S, Samaranch L, Vidal-Taboada JM, Lamet I, Bullido MJ, Frank-García A, Coria F, Lleó A, Clarimón J, Lorenzo E, Alonso E, Sánchez-Juan P, Rodríguez-Rodríguez E, Combarros O, Rosich M, Vilella E, Pastor P (2011) Genetic variation in APOE cluster region and Alzheimer's disease risk. Neurobiol Aging 22: 2107.e7-17.

Chiappelli M, Borroni B, Archetti S, Calabrese E, Corsi MM, Franceschi M, Padovani A, Licastro F (2006) VEGF gene and phenotype relation with Alzheimer's disease and mild cognitive impairment. Rejuvenation Res 9: 485-493.

Cornelis MC, Qi L, Zhang C, Kraft P, Manson J, Cai T, Hunter DJ, Hu FB (2009) Joint effects of common genetic variants on the risk for type 2 diabetes in U.S. men and women of European ancestry. Ann Intern Med 150: 541-550.

Davatzikos C, Bhatt P, Shaw LM, Batmanghelich KN, Trojanowski JQ (2011) Prediction of MCI to AD conversion, via MRI, CSF biomarkers, and pattern classification. Neurobiol Aging 32: 2322.e19-27. 
De Jager PL, Chibnik LB, Cui J, Reischl J, Lehr S, Simon KC, Aubin C, Bauer D, Heubach JF, Sandbrink R, Tyblova M, Lelkova P; Steering committee of the BENEFIT study; Steering committee of the BEYOND study; Steering committee of the LTF study; Steering committee of the CCR1 study, Havrdova E, Pohl C, Horakova D, Ascherio A, Hafler DA, Karlson EW (2009) Integration of genetic risk factors into a clinical algorithm for multiple sclerosis susceptibility: a weighted genetic risk score. Lancet Neurol 8: 1111-1119.

Elias-Sonnenschein LS, Viechtbauer W, Ramakers IH, Verhey FR, Visser PJ (2011) Predictive value of APOE- $\varepsilon 4$ allele for progression from MCI to AD-type dementia: a meta-analysis. J Neurol Neurosurg Psychiatry 82: 1149-1156.Ferris S, Nordberg A, Soininen H, Darreh-Shori T, Lane R (2009) Progression from mild cognitive impairment to Alzheimer's disease: effects of sex, butyrylcholinesterase genotype, and rivastigmine treatment. Pharmacogenet Genomics 19: 635-646. Forlenza OV, Diniz BS, Teixeira AL, Ojopi EB, Talib LL, Mendonça VA, Izzo G, Gattaz WF (2010) Effect of brain-derived neurotrophic factor Val66Met polymorphism and serum levels on the progression of mild cognitive impairment. World J Biol Psychiatry 11: 774-780.

Harold D, Abraham R, Hollingworth P, Sims R, Gerrish A, Hamshere ML, Pahwa JS, Moskvina V, Dowzell K, Williams A, Jones N, Thomas C, Stretton A, Morgan AR, Lovestone S, Powell J, Proitsi P, Lupton MK, Brayne C, Rubinsztein DC, Gill M, Lawlor B, Lynch A, Morgan K, Brown KS, Passmore PA, Craig D, McGuinness B, Todd S, Holmes C, Mann D, Smith AD, Love S, Kehoe PG, Hardy J, Mead S, Fox N, Rossor M, Collinge J, Maier W, Jessen F, Schürmann B, van den Bussche H, Heuser I, Kornhuber J, Wiltfang J, Dichgans M, Frölich L, Hampel H, Hüll M, Rujescu D, Goate AM, Kauwe JS, Cruchaga C, Nowotny P, Morris JC, Mayo K, Sleegers K, Bettens K, 
Engelborghs S, De Deyn PP, Van Broeckhoven C, Livingston G, Bass NJ, Gurling H, McQuillin A, Gwilliam R, Deloukas P, Al-Chalabi A, Shaw CE, Tsolaki M, Singleton AB, Guerreiro R, Mühleisen TW, Nöthen MM, Moebus S, Jöckel KH, Klopp N, Wichmann HE, Carrasquillo MM, Pankratz VS, Younkin SG, Holmans PA, O'Donovan M, Owen MJ, Williams J (2009) Genome-wide association study identifies variants at CLU and PICALM associated with Alzheimer's disease. Nat Genet 41: 1088-1093.

Hollingworth P, Harold D, Sims R, Gerrish A, Lambert JC, Carrasquillo MM, Abraham R, Hamshere ML, Pahwa JS, Moskvina V, Dowzell K, Jones N, Stretton A, Thomas C, Richards A, Ivanov D, Widdowson C, Chapman J, Lovestone S, Powell J, Proitsi P, Lupton MK, Brayne C, Rubinsztein DC, Gill M, Lawlor B, Lynch A, Brown KS, Passmore PA, Craig D, McGuinness B, Todd S, Holmes C, Mann D, Smith AD, Beaumont H, Warden D, Wilcock G, Love S, Kehoe PG, Hooper NM, Vardy ER, Hardy J, Mead S, Fox NC, Rossor M, Collinge J, Maier W, Jessen F, Rüther E, Schürmann B, Heun R, Kölsch H, van den Bussche H, Heuser I, Kornhuber J, Wiltfang J, Dichgans M, Frölich L, Hampel H, Gallacher J, Hüll M, Rujescu D, Giegling I, Goate AM, Kauwe JS, Cruchaga C, Nowotny P, Morris JC, Mayo K, Sleegers K, Bettens K, Engelborghs S, De Deyn PP, Van Broeckhoven C, Livingston G, Bass NJ, Gurling H, McQuillin A, Gwilliam R, Deloukas P, Al-Chalabi A, Shaw CE, Tsolaki M, Singleton AB, Guerreiro R, Mühleisen TW, Nöthen MM, Moebus S, Jöckel KH, Klopp N, Wichmann HE, Pankratz VS, Sando SB, Aasly JO, Barcikowska M, Wszolek ZK, Dickson DW, Graff-Radford NR, Petersen RC; the Alzheimer's Disease Neuroimaging Initiative, van Duijn CM, Breteler MM, Ikram MA, Destefano AL, Fitzpatrick AL, Lopez O, Launer LJ, Seshadri S; CHARGE consortium, Berr C, Campion D, Epelbaum J, Dartigues JF, Tzourio C, Alpérovitch A, Lathrop M; EADI1 consortium, Feulner TM, Friedrich P, Riehle C, Krawczak M, Schreiber S, Mayhaus M, Nicolhaus S, Wagenpfeil 
S, Steinberg S, Stefansson H, Stefansson K, Snædal J, Björnsson S, Jonsson PV, Chouraki V, Genier-Boley B, Hiltunen M, Soininen H, Combarros O, Zelenika D, Delepine M, Bullido MJ, Pasquier F, Mateo I, Frank-Garcia A, Porcellini E, Hanon O, Coto E, Alvarez V, Bosco P, Siciliano G, Mancuso M, Panza F, Solfrizzi V, Nacmias B, Sorbi S, Bossù P, Piccardi P, Arosio B, Annoni G, Seripa D, Pilotto A, Scarpini E, Galimberti D, Brice A, Hannequin D, Licastro F, Jones L, Holmans PA, Jonsson T, Riemenschneider M, Morgan K, Younkin SG, Owen MJ, O'Donovan M, Amouyel P, Williams J (2011) Common variants at ABCA7, MS4A6A/MS4A4E, EPHA1, CD33 and CD2AP are associated with Alzheimer's disease. Nat Genet 43: 429-435.

Jack CR Jr, Knopman DS, Jagust WJ, Shaw LM, Aisen PS, Weiner MW, Petersen RC, Trojanowski JQ (2010) Hypothetical model of dynamic biomarkers of the Alzheimer's pathological cascade. Lancet Neurol 9: 119-128.

Karlson EW, Chibnik LB, Kraft P, Cui J, Keenan BT, Ding B, Raychaudhuri S, Klareskog L, Alfredsson L, Plenge RM (2010) Cumulative association of twenty-two genetic variants with seropositive rheumatoid arthritits risk. Ann Rheum Dis 69: 1077-1085.

Lambert JC, Heath S, Even G, Campion D, Sleegers K, Hiltunen M, Combarros O, Zelenika D, Bullido MJ, Tavernier B, Letenneur L, Bettens K, Berr C, Pasquier F, Fiévet N, Barberger-Gateau P, Engelborghs S, De Deyn P, Mateo I, Franck A, Helisalmi S, Porcellini E, Hanon O; European Alzheimer's Disease Initiative Investigators, de Pancorbo MM, Lendon C, Dufouil C, Jaillard C, Leveillard T, Alvarez V, Bosco P, Mancuso M, Panza F, Nacmias B, Bossù P, Piccardi P, Annoni G, Seripa D, Galimberti D, Hannequin D, Licastro F, Soininen H, Ritchie K, Blanché H, Dartigues JF, Tzourio C, Gut I, Van Broeckhoven C, Alpérovitch A, Lathrop M, Amouyel P (2009) Genomewide association study identifies variants at CLU and CR1 associated with Alzheimer's disease. Nat Genet 41: 1094-1099. 
Landau SM, Harvey D, Madison CM, Reiman EM, Foster NL, Aisen PS, Petersen RC, Shaw LM, Trojanowski JQ, Jack CR Jr, Weiner MW, Jagust WJ; Alzheimer's Disease Neuroimaging Initiative (2010) Comparing predictors of conversion and decline in mild cognitive impairment. Neurology 75: 230-238.

Naj AC, Jun G, Beecham GW, Wang LS, Vardarajan BN, Buros J, Gallins PJ, Buxbaum JD, Jarvik GP, Crane PK, Larson EB, Bird TD, Boeve BF, Graff-Radford NR, De Jager PL, Evans D, Schneider JA, Carrasquillo MM, Ertekin-Taner N, Younkin SG, Cruchaga C, Kauwe JS, Nowotny P, Kramer P, Hardy J, Huentelman MJ, Myers AJ, Barmada MM, Demirci FY, Baldwin CT, Green RC, Rogaeva E, St George-Hyslop P, Arnold SE, Barber R, Beach T, Bigio EH, Bowen JD, Boxer A, Burke JR, Cairns NJ, Carlson CS, Carney RM, Carroll SL, Chui HC, Clark DG, Corneveaux J, Cotman CW, Cummings JL, DeCarli C, DeKosky ST, Diaz-Arrastia R, Dick M, Dickson DW, Ellis WG, Faber KM, Fallon KB, Farlow MR, Ferris S, Frosch MP, Galasko DR, Ganguli M, Gearing M, Geschwind DH, Ghetti B, Gilbert JR, Gilman S, Giordani B, Glass JD, Growdon JH, Hamilton RL, Harrell LE, Head E, Honig LS, Hulette CM, Hyman BT, Jicha GA, Jin LW, Johnson N, Karlawish J, Karydas A, Kaye JA, Kim R, Koo EH, Kowall NW, Lah JJ, Levey AI, Lieberman AP, Lopez OL, Mack WJ, Marson DC, Martiniuk F, Mash DC, Masliah E, McCormick WC, McCurry SM, McDavid AN, McKee AC, Mesulam M, Miller BL, Miller CA, Miller JW, Parisi JE, Perl DP, Peskind E, Petersen RC, Poon WW, Quinn JF, Rajbhandary RA, Raskind M, Reisberg B, Ringman JM, Roberson ED, Rosenberg RN, Sano M, Schneider LS, Seeley W, Shelanski ML, Slifer MA, Smith CD, Sonnen JA, Spina S, Stern RA, Tanzi RE, Trojanowski JQ, Troncoso JC, Van Deerlin VM, Vinters HV, Vonsattel JP, Weintraub S, Welsh-Bohmer KA, Williamson J, Woltjer RL, Cantwell LB, Dombroski BA, Beekly D, Lunetta KL, Martin ER, Kamboh MI, Saykin AJ, Reiman EM, Bennett DA, Morris JC, Montine TJ, Goate AM, Blacker 
D, Tsuang DW, Hakonarson H, Kukull WA, Foroud TM, Haines JL, Mayeux R, Pericak-Vance MA, Farrer LA, Schellenberg GD (2011) Common variants at MS4A4/MS4A6E, CD2AP, CD33 and EPHA1 are associated with late-onset Alzheimer's disease. Nat Genet 43: 436-441.

Petersen RC, Doody R, Kurz A, Mohs RC, Morris JC, Rabins PV, Ritchie K, Rossor M, Thal L, Winblad B (2001) Current concepts in mild cognitive impairment. Arch Neurol 58: 1985-1992.

Pozueta A, Vázquez-Higuera JL, Sánchez-Juan P, Rodríguez-Rodríguez E, Sánchez-Quintana C, Mateo I, Berciano J, Combarros O (2011) Genetic variation in caspase-1 as predictor of accelerated progression from mild cognitive impairment to Alzheimer's disease. J Neurol 258: 1538-1539.

Reitz C, Mayeux R (2010) Use of genetic variation as biomarkers for mild cognitive impairment and progression of mild cognitive impairment to dementia. J Alzheimers Dis 19: 229-251.

Ripatti S, Tikkanen E, Orho-Melander M, Havulinna AS, Silander K, Sharma A, Guiducci C, Perola M, Jula A, Sinisalo J, Lokki ML, Nieminen MS, Melander O, Salomaa V, Peltonen L, Kathiresan S (2010) A multilocus genetic risk score for coronary heart disease: case-control and prospective cohort analyses. Lancet 376: 1393-1400.

Samaranch L, Cervantes S, Barabash A, Alonso A, Cabranes JA, Lamet I, Ancín I, Lorenzo E, Martínez-Lage P, Marcos A, Clarimón J, Alcolea D, Lleó A, Blesa R, Gómez-Isla T, Pastor P (2010) The effect of MAPT H1 and APOE $\varepsilon 4$ on transition from mild cognitive impairment to dementia. J Alzheimers Dis 22: 1065-1071.

Seshadri S, Fitzpatrick AL, Ikram MA, DeStefano AL, Gudnason V, Boada M, Bis JC, Smith AV, Carassquillo MM, Lambert JC, Harold D, Schrijvers EM, Ramirez-Lorca R, Debette S, Longstreth WT Jr, Janssens AC, Pankratz VS, Dartigues JF, Hollingworth P, 
Aspelund T, Hernandez I, Beiser A, Kuller LH, Koudstaal PJ, Dickson DW, Tzourio C, Abraham R, Antunez C, Du Y, Rotter JI, Aulchenko YS, Harris TB, Petersen RC, Berr C, Owen MJ, Lopez-Arrieta J, Varadarajan BN, Becker JT, Rivadeneira F, Nalls MA, Graff-Radford NR, Campion D, Auerbach S, Rice K, Hofman A, Jonsson PV, Schmidt H, Lathrop M, Mosley TH, Au R, Psaty BM, Uitterlinden AG, Farrer LA, Lumley T, Ruiz A, Williams J, Amouyel P, Younkin SG, Wolf PA, Launer LJ, Lopez OL, van Duijn CM, Breteler MM; CHARGE Consortium; GERAD1 Consortium; EADI1 Consortium (2010) Genome-wide analysis of genetic loci associated with Alzheimer disease. JAMA 303: 1832-1840. 
Figure 1. Effect of genetic risk score (GRS) divided into tertiles on survival time (Cox survival analysis graph) to Alzheimer's disease (AD) in patients with mild cognitive impairment (MCI). The y-axis shows the cumulative proportion of MCI-nonconverters to AD for any given follow-up period on the x-axis. 
Table 1. Predictive variables of conversion from Mild Cognitive Impairment to Alzheimer's disease

\begin{tabular}{|c|c|c|c|}
\hline Variable & Odds Ratio & $95 \%$ CI & $p$-value \\
\hline \multicolumn{4}{|l|}{ MODEL $1^{*}$} \\
\hline APOE $\varepsilon 4$ allele vs non- $\varepsilon 4$ allele carriers & 4.63 & $2.15-9.98$ & $<0.001$ \\
\hline ABCA7 (rs3764650) G allele vs non-G allele carriers & 1.80 & $0.75-4.31$ & 0.183 \\
\hline BIN1 (rs744373) G allele vs non-G allele carriers & 1.69 & $0.81-3.54$ & 0.157 \\
\hline CD2AP (rs9296559) C allele vs non-C allele carriers & 1.50 & $0.71-3.16$ & 0.280 \\
\hline CLU (rs11136000) T allele vs non-T allele carriers & 0.25 & $0.07-0.84$ & 0.025 \\
\hline CR1 (rs1408077) T allele vs non-T allele carriers & 1.03 & $0.47-2.26$ & 0.934 \\
\hline MS4A4E (rs670139) T allele vs non-T allele carriers & 1.15 & $0.49-2.68$ & 0.734 \\
\hline MS4A6A (rs610932) T allele vs non-T allele carriers & 1.26 & $0.43-3.70$ & 0.667 \\
\hline PICALM (rs3851179) A allele vs non-A allele carriers & 0.49 & $0.16-1.46$ & 0.203 \\
\hline \multicolumn{4}{|l|}{ MODEL $2^{* *}$} \\
\hline APOE $\varepsilon 4$ allele vs non- $\varepsilon 4$ allele carriers & 4.56 & $2.23-9.38$ & $<0.001$ \\
\hline GRS $2^{\text {nd }}$ tertile vs $1^{\text {st }}$ tertile ${ }^{* *}$ & 1.43 & $0.61-3.34$ & 0.407 \\
\hline GRS $3^{\text {rd }}$ tertile vs $1^{\text {st }}$ tertile ${ }^{* *}$ & 1.32 & $0.57-3.06$ & 0.505 \\
\hline
\end{tabular}

*Odds ratio tested with logistic regression model adjusted for age, sex, APOE, ABCA7, BIN1, CD2AP, CLU, CR1, MS4A4E, MS4A6A, and PICALM. ${ }^{* *}$ Odds ratio tested with logistic regression model adjusted for age, sex, APOE, and GRS (see methods for Genetic Risk Score calculation) divided into tertiles 


\begin{tabular}{|c|c|c|c|}
\hline Variable & Hazard Ratio & $95 \%$ CI & $p$-value \\
\hline \multicolumn{4}{|l|}{ MODEL $1^{*}$} \\
\hline APOE $\varepsilon 4$ allele vs non- $\varepsilon 4$ allele carriers & 1.77 & $1.05-2.97$ & 0.030 \\
\hline ABCA7 (rs3764650) G allele vs non-G allele carriers & 1.25 & $0.68-2.28$ & 0.459 \\
\hline BIN1 (rs744373) G allele vs non-G allele carriers & 1.31 & $0.77-2.23$ & 0.315 \\
\hline CD2AP (rs9296559) C allele vs non-C allele carriers & 1.69 & $0.99-2.85$ & 0.051 \\
\hline CLU (rs11136000) T allele vs non-T allele carriers & 0.84 & $0.39-1.80$ & 0.666 \\
\hline CR1 (rs1408077) T allele vs non-T allele carriers & 1.15 & $0.66-1.97$ & 0.613 \\
\hline MS4A4E (rs670139) T allele vs non-T allele carriers & 0.92 & $0.49-1.72$ & 0.802 \\
\hline MS4A6A (rs610932) T allele vs non-T allele carriers & 1.42 & $0.61-3.30$ & 0.416 \\
\hline PICALM (rs3851179) A allele vs non-A allele carriers & 0.56 & $0.25-1.24$ & 0.155 \\
\hline \multicolumn{4}{|l|}{ MODEL $2^{* *}$} \\
\hline APOE $\varepsilon 4$ allele vs non- $\varepsilon 4$ allele carriers & 1.60 & $0.98-2.60$ & 0.057 \\
\hline GRS $2^{\text {nd }}$ tertile vs $1^{\text {st }}$ tertile ${ }^{* *}$ & 1.89 & $1.01-3.56$ & 0.047 \\
\hline GRS $3^{\text {rd }}$ tertile vs $1^{\text {st }}$ tertile ${ }^{* *}$ & 2.06 & $1.07-3.98$ & 0.031 \\
\hline
\end{tabular}

*Hazard ratio tested with Cox regression model adjusted for age, sex, APOE, ABCA7, BIN1, CD2AP, CLU, CR1, MS4A4E, MS4A6A, and PICALM. ${ }^{* *}$ Hazard ratio tested with Cox regression model adjusted for age, sex, APOE, and GRS (see methods for Genetic Risk Score calculation) divided into tertiles 